\title{
An archaeometric study of Hellenistic glass vessels: evidence for multiple sources
}

\author{
A. Oikonomou ${ }^{1} \cdot$ J. Henderson ${ }^{1} \cdot$ M. Gnade ${ }^{2} \cdot$ S. Chenery ${ }^{3} \cdot$ N. Zacharias ${ }^{4}$
}

Received: 11 February 2016 / Accepted: 11 April 2016/Published online: 16 May 2016

(C) The Author(s) 2016. This article is published with open access at Springerlink.com

\begin{abstract}
In the present study, 53 glass fragments from coreformed vessels and 3 glass beads are investigated using SEM/ EDX, EPMA and LA-ICP-MS. All samples were excavated in the Latin settlement of Satricum in central west Italy and apart from two, were found in the so-called fourth-third c. BC Hellenistic Votive deposit, also known as Votive Deposit III, discovered in front of the sanctuary of Mater Matuta on top of the acropolis. The analytical results indicate that the glass from Satricum is a typical soda-lime-silica type with natron used as a flux. Its chemical compositions display a relatively low compositional variation. Small differences in the concentrations of major and minor oxides $\left(\mathrm{SiO}_{2}, \mathrm{Al}_{2} \mathrm{O}_{3}, \mathrm{CaO}\right.$ and $\left.\mathrm{Fe}_{2} \mathrm{O}_{3}\right)$ and in trace elements ( $\mathrm{Sr}, \mathrm{Zr}$ and $\mathrm{Nd}$ ) between individual samples suggest the use of different types of raw materials, especially sand. In turn, this suggests that the glass derived from more than one glass making centre. The combined investigation of colourants $(\mathrm{Co}, \mathrm{Cu}$ and $\mathrm{Mn})$ reinforces and confirms the idea that glass from Satricum was made using different manufacturing traditions during the Hellenistic period.
\end{abstract}

A. Oikonomou

artemios.oikonomou@nottingham.ac.uk;

artemoikonomou@gmail.com

1 Department of Archaeology, University of Nottingham, University Park, Nottingham NG7 2RD, UK

2 Faculteit der GeesteswetenschappenCapaciteitsgroepArcheologie (AAC), University of Amsterdam, Turfdraagsterpad 9, 1012 XT, Amsterdam, The Netherlands

3 British Geological Survey, Keyworth, Nottingham NG12 5GG, UK

4 Department of History, Archaeology and Cultural Resources Management, University of Peloponnese, Old Camp, 24100 Kalamata, Greece
Keywords Natron glass $\cdot$ Core-formed vessels $\cdot$ Hellenistic period $\cdot$ Italy $\cdot$ Satricum $\cdot$ Trace elements $\cdot$ Chemical composition $\cdot$ SEM-EDX $\cdot$ EPMA $\cdot$ LA-ICP-MS

\section{Introduction}

Archeometric glass studies have focused on the analysis of material from various periods, from Bronze Age to the Middle Ages. The scientific community has been mainly interested in investigating glass dating from the Late Bronze Age (fourteenth to twelfth c. BC) and from late antiquity (first to ninth $\mathrm{c}$. $\mathrm{AD}$ ) while little interest has been given to glass from the intervening period (seventh to first c. BC) (Brill 1999; Triantafyllidis 2000a, b; Rehren et al. 2005; Zacharias et al. 2008a, b; Oikonomou et al. 2008; Sokaras et al. 2009; Arletti et al. 2011; Beltsios et al. 2012; Connolly et al. 2012; Oikonomou et al. 2012; Triantafyllidis et al. 2012; Oikonomou et al. 2014; Palamara et al. 2015; Rehren et al. 2015). The focus of this paper is an analytical study of early Hellenistic glass excavated in Satricum, Italy, in order to redress the balance of our knowledge for glass from this time period. Little is known about primary or secondary glass production during Hellenistic times. The main objectives of this work are to shed light to the glass technology used in this period and to try to answer suggest a provenance for the glasses.

The glass finds investigated in this paper come from the Latin settlement of Satricum situated on the banks of the river Astura, ca. $60 \mathrm{~km}$ south of Rome (Fig. 1). This settlement developed from a modest hamlet of huts in the ninth c. BC, perched on top of an 'acropolis' hill, into a prosperous urban centre in by the sixth c. BC covering an area of nearly 40 ha. The site was discovered in the late nineteenth c., after which Italian archaeologists excavated large parts of the settlement (1896-1898 and 1907-1910). Research in Satricum was taken 
Fig. 1 Map indicating the location of the sites discussed in this paper

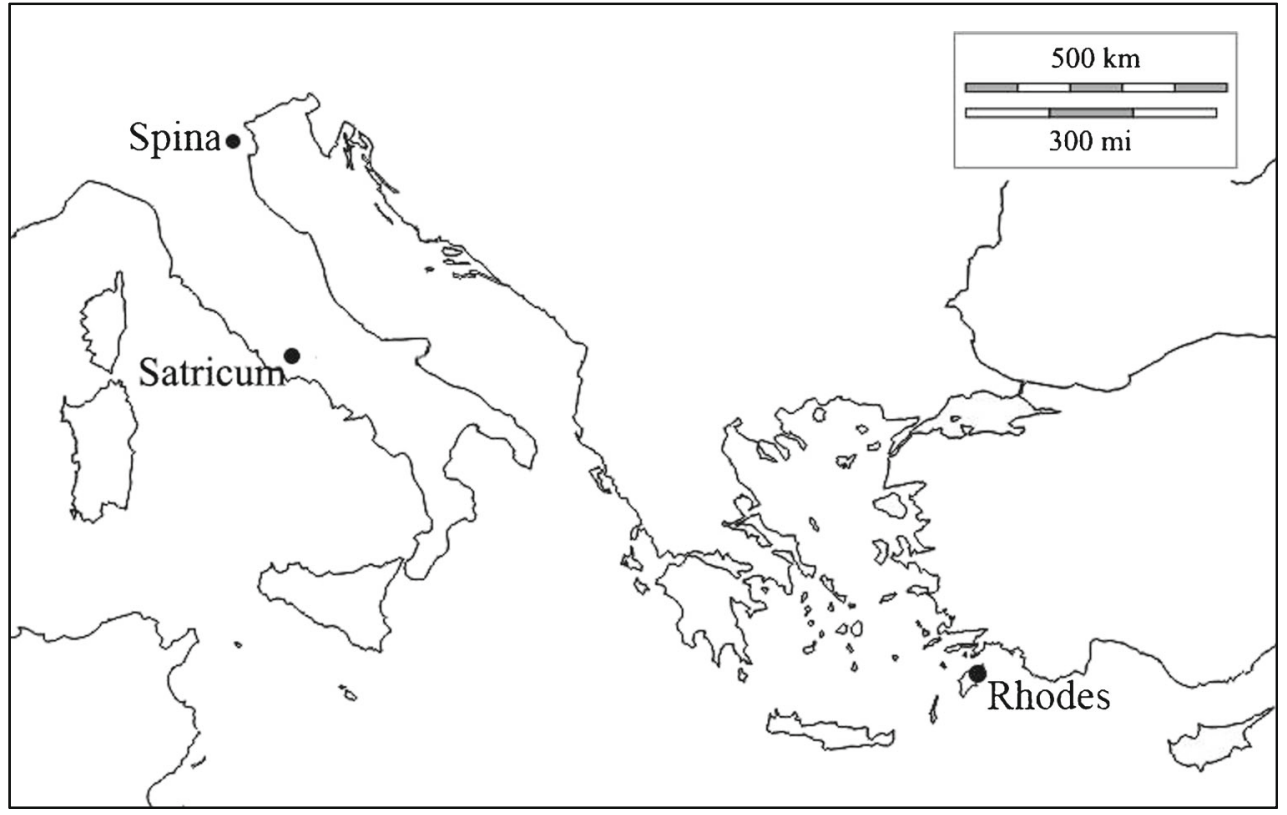

up again in 1977 by Dutch archaeologists who are still active on the site.

Satricum's favourable location at the crossroads between the northern Etruscan and southern Greek areas is reflected in the remarkable diversity of the archaeological material. At the same time, it is one of the best preserved sites in central Italy revealing archaeological remains which cover a period of continuous occupation from nearly ten centuries (ninth c. BCfirst c. AD). The site is probably best known for its sanctuary dedicated to Mater Matuta, goddess of dawn. Situated on top of the acropolis, it incorporates three successive temple buildings from the Archaic period onwards. The importance of the sanctuary is reflected in three substantial votive deposits which testify to offering practices over a long period of time. Among them is the so-called Hellenistic Votive deposit, also known as Votive Deposit III, discovered in front of the temple at the end of the nineteenth c. During the re-excavation of the deposit between 1986 and 1990, substantial numbers of exvoto came to light that were either not excavated by the nineteenth c. excavators or left behind by them because of their fragmented state of preservation. Among these finds which consisted of a large variety of Hellenistic ceramics as well as numerous categories of terracotta votive offerings, some 140 fragments of core-formed glass flasks and several glass beads were found. ${ }^{1}$ So far, this is the largest corpus of Hellenistic core glass vessels known in Latium. The fragments of the core-formed vessels belong to the Mediterranean Group II industry which dates between mid fourth to third c. BC. Core-formed vessels of the first millennium $\mathrm{BC}$ can be

\footnotetext{
${ }^{1}$ The core-formed glass vessels are presently under study as part of a larger project concerning the publication of all votive offerings found in the Hellenistic votive deposit.
}

distinguished in three major glass industries (Mediterranean groups I, II and III) that prevailed in Mediterranean area between mid sixth c. BC to early first c. AD. The typology of these glass vessels follows the typical shapes of pottery and metalware of Archaic, Classical and Hellenistic periods such as alabastra, amphoriskoi, oinochoai and aryballoi (Grose 1989; Stern and Schlick-Nolte 1994). The material constitutes an exotic category among the predominantly central Italian objects in the votive deposit. The current study aims to improve our knowledge on the composition of the glass and the provenance of the material, thus providing valuable information on the position of Satricum in the commercial networks of this period (Gnade 2002, 2007).

\section{Materials and methods}

\section{Materials}

In the present study, 53 fragments of core-formed glass vessels and 3 fragments of glass beads are investigated. The samples come from various vessels types. Specifically, the vessel assemblage consists of 25 alabastra, 8 oinochoai, 7 amphoriskoi, 4 hydriskoi, 1 aryballos and 8 unidentified glass vessels. The beads assemblage consists of 2 eye beads and 1 bead with white decorative trails (Table 1). The majority of glass vessels bear opaque white or/and yellow decorative zigzag or straight trails, while there are few examples of blue and turquoise decorative trails (Fig. 2).

Small pieces (2-3 $\mathrm{mm}$ ) were cut from the vessel fragments using a diamond cutting disc. The samples were mounted in a resin block. The resin block was ground with silicon carbide 
Table 1 General description of the glass artefacts analysed

\begin{tabular}{|c|c|c|c|c|c|c|}
\hline Sample & Main body colour & Decoration colour/type & Vessel part & Typology & Analytical technique & Group \\
\hline Sa.4 & Dark blue & - & Unidentified & Unidentified & SEM/ICP & A \\
\hline Sa.5 & Turquoise & Yellow & Rim & Alabastron & $\mathrm{SEM} / \mathrm{ICP}$ & A \\
\hline Sa.16 & Dark blue & White/zigzag & Body & Alabastron & SEM/ICP & $\mathrm{A}$ \\
\hline Sa.21 & Turquoise & Yellow and white/feather & Body & Alabastron & SEM/ICP & $\mathrm{A}$ \\
\hline Sa.35 & Dark blue & Yellow and white/festoon & Body & Aryballos & $\mathrm{SEM} / \mathrm{ICP}$ & $\mathrm{A}$ \\
\hline $\mathrm{Sa} .40$ & Brown & Yellow, white and Turquoise/feather & Body & Oinochoe & SEM/ICP & A \\
\hline SAT.5 & Blue & Yellow and white & Shoulder & Unidentified & EPMA & A \\
\hline Sa.1 & Dark blue & - & Unidentified & Alabastron & SEM/ICP & $\mathrm{B}$ \\
\hline Sa.2 & Dark blue & - & Rim & Alabastron & SEM/ICP & $\mathrm{B}$ \\
\hline Sa.3 & Dark blue & - & Body & Alabastron & SEM/ICP & $\mathrm{B}$ \\
\hline Sa.6-14 & Dark blue & Yellow and white/zig zag & Body & Alabastron & SEM/ICP & $\mathrm{B}$ \\
\hline Sa.15, 17-20, 22 & Dark blue & Yellow and white/feather & Body & Alabastron & SEM/ICP & $\mathrm{B}$ \\
\hline Sa.23 & Dark blue & White/feather & Body & Alabastron & SEM/ICP & $\mathrm{B}$ \\
\hline $\mathrm{Sa} .24$ & Dark blue & Yellow and white/zig zag & Body & Alabastron & SEM/ICP & $\mathrm{B}$ \\
\hline Sa.25-27 & Dark blue & Yellow/straight & Body & Amphoriskos & SEM/ICP & $\mathrm{B}$ \\
\hline Sa.28-29 & Brown & Yellow and white/zig zag & Body & Amphoriskos & SEM/ICP & $\mathrm{B}$ \\
\hline Sa. 30 & Brown & Yellow and white/straight & Body & Amphoriskos & SEM/ICP & $\mathrm{B}$ \\
\hline Sa.31 & Dark blue & - & Body & Hydriskos & SEM/ICP & $\mathrm{B}$ \\
\hline Sa.32-33 & Dark blue & Yellow and white/straight & Body & Hydriskos & SEM/ICP & B \\
\hline Sa.34 & Dark blue & - & Base & Hydriskos & SEM/ICP & $\mathrm{B}$ \\
\hline Sa.36-37 & Dark blue & Yellow and white/straight & Body & Oinochoe & SEM/ICP & $\mathrm{B}$ \\
\hline Sa.38-39 & Dark blue & White/zigzag & Body & Oinochoe & SEM/ICP & $\mathrm{B}$ \\
\hline $\mathrm{Sa} .41$ & Dark blue & Yellow/straight & Body & Oinochoe & SEM/ICP & $\mathrm{B}$ \\
\hline Sa. 42 & Dark blue & - & Base & Oinochoe & $\mathrm{SEM} / \mathrm{ICP}$ & $\mathrm{B}$ \\
\hline $\mathrm{Sa} .43$ & Dark blue & Yellow/zigzag & - & Bead & SEM/ICP & $\mathrm{B}$ \\
\hline Sa.44-45 & Dark blue & White/eyes & - & Eye bead & SEM/ICP & $\mathrm{B}$ \\
\hline SAT.2 & Dark blue & Yellow/straight & Base & Pinochoe & EPMA & $\mathrm{B}$ \\
\hline SAT.1 & Dark blue & Yellow and white/trails & Body & Amphoriskos & EPMA & $\mathrm{C}$ \\
\hline SAT.3 & Dark blue & Yellow & Neck and shoulder & Unidentified & EPMA & $\mathrm{C}$ \\
\hline SAT.4 & Dark blue & - & Neck & Alabastron & EPMA & $\mathrm{C}$ \\
\hline SAT.6 & Dark blue & Yellow/zigzag & Body & Unidentified & EPMA & $\mathrm{C}$ \\
\hline SAT.7 & Dark blue & Yellow, white and turquoise & Body & Unidentified & EPMA & $\mathrm{C}$ \\
\hline SAT.8 & Dark blue & Yellow and white/trails & Body & Unidentified & EPMA & $\mathrm{C}$ \\
\hline SAT.9 & Dark blue & Yellow and white/trails & Rim & Unidentified & EPMA & $\mathrm{C}$ \\
\hline SAT.10 & Dark blue & Yellow and white/trails & Body & Unidentified & EPMA & $\mathrm{C}$ \\
\hline SAT.11 & Dark blue & No & Rim & Unidentified & EPMA & outlier \\
\hline
\end{tabular}

paper of various grits $(600,800,1200,2500)$ and then polished using diamond paste of $6-3$ and $1 \mu \mathrm{m}$.

\section{Scanning electron microscopy/energy dispersive X-ray spectrometry (SEM/EDX)}

Scanning electron microscopy was the analytical technique used for the detection of major and minor elements of 45 glass samples (42 vessels and 3 beads). A JEOL (JSM$6510 \mathrm{LV}$ ) scanning electron microscope, coupled with an energy-dispersive X-ray spectrometer Oxford instruments, was used. All samples were analysed under high vacuum, with an operating voltage at $20 \mathrm{kV}$ and working distance for each sample of $15 \mathrm{~mm}$. The calibration of the system was performed with geological standards and the accuracy/ precision it was established by analysing standard reference materials (NIST SRM620, SRM1831 and SRM612). The analyses are in close agreement with the expected values and are presented in Table 2. The relative error between the expected and measured values is approximately $5 \%$ for most 
a
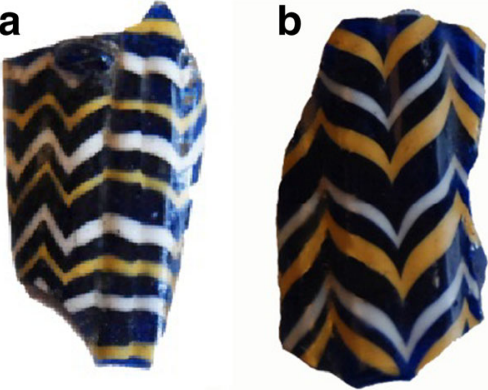

d

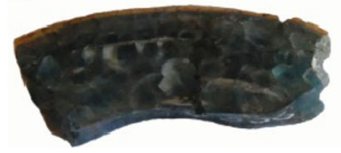

C

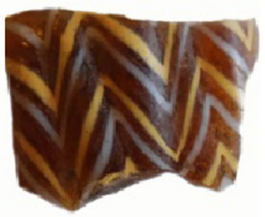

e

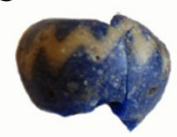

Fig. 2 Sample fragments from Satricum. Clockwise from top left: a Cobalt blue core-formed alabastron, b Cobalt blue core-formed alabastron, $\mathbf{c}$ Brown core-formed amphoriskos, $\mathbf{d}$ Blue green (turquoise) rim from a core-formed alabastron, e Cobalt blue bead with opaque yellow zigzag trail

of the oxides. Due to submicrometer beam size, 5 analyses of $300 \mathrm{~s}$ were performed on each sample, and the mean value was calculated for each element.

\section{Electron probe micro analysis (EPMA)}

Electron probe microanalyses were carried out by Dr. Andy Tindle in order to detect major and minor elements in 11 fragments of core-formed vessels (see Table 5). A Cameca SX50 is located at the Department of environment, earth and ecosystems, The Open University was run at $20 \mathrm{kV}$ accelerating voltage and $20 \mathrm{nA}$ beam current. Quantitative analyses were produced for all major, minor and trace elements detected. Analyses were performed using a defocused electron beam of $20 \mu \mathrm{m}$ in diameter so as to prevent the volatilisation of light (low atomic number) elements such as soda and magnesium. Multi-element glass standards (Corning glass standards and NIST) were analysed on a regular basis so as to establish and monitor the accuracy and precision of the machine. Table 3 provides a comparison of quoted oxide results compared with our measured results with associated standard deviations. The levels of detection varied from $170 \mathrm{ppm}$ for $\mathrm{CaO}$ to $1200 \mathrm{ppm}$ for $\mathrm{CuO}$. A ZAF programme was used to correct and quantify the results.

\section{Laser-ablated inductively plasma mass spectrometry (LA-ICP-MS)}

Trace element analysis was performed by laser ablation-inductively coupled plasma-mass spectrometry (LA-ICPMS). The LA-ICP-MS instrument consisted of a NewWave UP193FX excimer (193 nm) laser system with built in microscope imaging coupled to an Agilent 7500 series ICP-MS. Laser ablation craters were set at $70 \mu \mathrm{m}$, the laser being fired

Table 2 Measured and expected values of major and minor oxides for standard reference materials (in $\%$ wt.)

\begin{tabular}{llllllll}
\hline SAMPLE & $\mathrm{Na}_{2} \mathrm{O}$ & $\mathrm{MgO}$ & $\mathrm{Al}_{2} \mathrm{O}_{3}$ & $\mathrm{SiO}_{2}$ & $\mathrm{SO}_{3}$ & $\mathrm{~K}_{2} \mathrm{O}$ & $\mathrm{CaO}$ \\
\hline SRM620 & 14.19 & 3.66 & 1.72 & 73.59 & 0.21 & 0.39 & 6.27 \\
Expected & 14.39 & 3.69 & 1.8 & 72.08 & 0.28 & 0.41 & 7.11 \\
SRM1831 & 13.67 & 3.67 & 1.20 & 74.03 & 0.27 & 0.29 & 6.9 \\
Expected & 13.32 & 3.51 & 1.21 & 73.08 & 0.25 & 0.33 & 8.2 \\
SRM612 & 13.94 & - & 2.06 & 72.93 & - & - & 11.08 \\
Expected & 13.7 & - & 2.03 & 72.1 & - & - & 11.9 \\
\hline
\end{tabular}

The expected values for SRM612 were provided by GeoRem (Jochum et al. 2011)

for $45 \mathrm{~s}$ at $10 \mathrm{~Hz}$ and a typical fluence of $2.8 \mathrm{Jcm}^{-2}$. Data was collected in a time resolved analysis mode, with a gas blank being measured before a series of ablations on glass samples, calibration standards and quality control standards, were carried out. Calibration standards bracketed the samples and QC over a period of $1 \mathrm{~h}$ or less.

Calibration of the system was performed using NIST SRM610 trace element glass standard. The measured and expected values are presented in Table 4. NIST SRM612 was used for quality control purposes.

\section{Results and discussion}

\section{Type of glass}

All Satricum samples are of a soda-lime-silica type (Sayre and Smith 1961). Silicon dioxide $\left(\mathrm{SiO}_{2}\right)$, the main glass former, varies between $68.61 \%$ wt. and $74.01 \%$ wt. with a mean value of $70.58 \% \mathrm{wt}$. The main source of $\mathrm{SiO}_{2}$ can be either sand or crushed quartzite pebbles. Sand, a less pure source than quartz, exhibits elevated amounts of impurities such as aluminium oxide $\left(\mathrm{Al}_{2} \mathrm{O}_{3}\right)$ and iron oxide $\left(\mathrm{Fe}_{2} \mathrm{O}_{3}\right)$ (Nicholson and Henderson 2000). In the present study, the mean values of $\mathrm{Al}_{2} \mathrm{O}_{3}$ and $\mathrm{Fe}_{2} \mathrm{O}_{3}$ are $2.08 \%$ wt. and $0.24 \%$ wt., respectively, close to the typical values of such impurities found in sands; although we are not suggesting this as a source, sand from the Belus river on the Levantine coast is thought to have been a suitable sand source used during antiquity, containing $2.98 \%$ wt. $\mathrm{Al}_{2} \mathrm{O}_{3}$ and $0.325 \%$ wt. $\mathrm{Fe}_{2} \mathrm{O}_{3}$, values that do not change significantly the base glass composition (Brill 1988). When evaluating potential sand sources, it should be considered that they exhibit variability in their chemical composition and not all sands are suitable for glassmaking (Brems et al. 2012; Degryse 2014).

Potassium oxide $\left(\mathrm{K}_{2} \mathrm{O}\right)$ and magnesium oxide $(\mathrm{MgO})$ are found in concentrations below $1 \%$ wt., indicating that natron was the flux used to introduce a mean sodium oxide $\left(\mathrm{Na}_{2} \mathrm{O}\right)$ level of $17.55 \%$ wt. The evaporite deposits consist of sodiumrich minerals such as natron $\left(\mathrm{Na}_{2} \mathrm{CO}_{3} \cdot 10 \mathrm{H}_{2} \mathrm{O}\right)$ and/or trona 
Table 3 The recommended composition for the Corning B standard (Wagner et al. 2012) compared to average analytical results $(n=22)$ and associated standard deviations using the electron microprobe (in \% wt.)

\begin{tabular}{lccccccccccccc}
\hline & $\mathrm{SiO}_{2}$ & $\mathrm{Al}_{2} \mathrm{O}_{3}$ & $\mathrm{Na}_{2} \mathrm{O}$ & $\mathrm{K}_{2} \mathrm{O}$ & $\mathrm{CaO}$ & $\mathrm{TiO}_{2}$ & $\mathrm{Fe}_{2} \mathrm{O}_{3}$ & $\mathrm{MnO}$ & $\mathrm{MgO}$ & $\mathrm{CoO}^{2}$ & $\mathrm{CuO}_{2} \mathrm{P}_{2} \mathrm{O}_{5}$ & $\mathrm{Sb}_{2} \mathrm{O}_{3}$ \\
\hline Measured & 60.76 & 4.18 & 17.35 & 1.02 & 8.51 & 0.1 & 0.33 & 0.24 & 1.02 & 0.05 & 2.95 & 0.81 & 0.67 \\
Quoted & 62.02 & 4.63 & 16.5 & 1.3 & 8.75 & 0.099 & 0.31 & 0.24 & 0.99 & 0.043 & 2.82 & 0.61 & 0.42 \\
St. dev. & 1.03 & 0.04 & 0.17 & 0.03 & 0.27 & 0.02 & 0.03 & 0.03 & 0.05 & 0.02 & 0.09 & 0.11 & 0.08 \\
\hline
\end{tabular}

$\left(\mathrm{Na}_{2} \mathrm{CO}_{3} \cdot \mathrm{NaHCO}_{3} \cdot 2 \mathrm{H}_{2} \mathrm{O}\right)$ (Shortland 2004; Henderson 2013). Calcium oxide ( $\mathrm{CaO}$, with a mean value $6.90 \%$ wt.) can be introduced in the glass either but unlikely as a deliberate additive or usually as in our case as an impurity in the form of marine shells in coastal sands (Henderson 2013) or freshwater shells in river sands.

The majority of samples have a deep blue colour. Their colouration is attributed to the simultaneous presence of both cobalt $(\mathrm{Co})$ and copper $(\mathrm{Cu})$ which have mean values of 1132 and $1713 \mathrm{mg} / \mathrm{kg}$, respectively. Two samples have a turquoise colour because of the elevated amount of $\mathrm{Cu}$ (5542 and $5307 \mathrm{mg} / \mathrm{kg}$ ), while four samples are brown but without significantly high values of colourant elements (e.g., Fe, Mn, $\mathrm{Cu}$ ). Their colouration is probably due to varied furnace atmospheres (Henderson 2000). These samples have elevated boron concentrations (above $350 \mathrm{mg} / \mathrm{kg}$ ), which is an additional chemical discriminant, while the mean value in boron of the remaining samples is $177 \mathrm{mg} / \mathrm{kg}$. Opacity in yellow and white glasses is due to the presence of antimony $\mathrm{Sb}$ and lead $\mathrm{Pb}$ which have mean values of 717 and $2049 \mathrm{mg} / \mathrm{kg}$, respectively. Calcium and lead antimonate crystals are responsible for the opacity of ancient glass (Lahlil et al. 2008).

\section{Sand source}

$\mathrm{Al}_{2} \mathrm{O}_{3}$ is present in varying amounts in most glass artefacts in antiquity. It is introduced in the glass batch most of the time as an impurity in the sand used in glassmaking (Jackson et al. 2005; Nicholson and Henderson 2000); we should not exclude its deliberate addition (Beltsios et al. 2012) which is not the case in the samples in this study. Therefore, $\mathrm{Al}_{2} \mathrm{O}_{3}$ is a possible way to differentiate between primary sand sources. A bi-plot of $\mathrm{SiO}_{2}$ and $\mathrm{Al}_{2} \mathrm{O}_{3}$ in Satricum samples and coeval samples from Spina, Italy (Arletti et al. 2011) and Rhodes Island, Greece (Triantafyllidis et al. 2012) is shown in Fig. 3. Furthermore, in the same figure, the concentrations of two hypothetical glasses derived from suitable Italian sands for glassmaking, according to Brems et al. (2012), are plotted.

All samples can be divided in 3 basic groups according to their $\mathrm{SiO}_{2}$ and $\mathrm{Al}_{2} \mathrm{O}_{3}$ levels. The first group (group $\mathrm{A}$ ) has values of $\mathrm{SiO}_{2}$ and $\mathrm{Al}_{2} \mathrm{O}_{3}$ above $68 \%$ wt. and below $1.5 \%$ wt., respectively, consisting of 7 Satricum samples and 2 samples from Spina (low $\mathrm{Al}_{2} \mathrm{O}_{3}$ group). The second group (group B) has values above $68 \%$ wt. and $1.5 \%$ wt. respectively, consisting of the majority of Satricum samples (40 samples out of 56) and 6 samples from Spina, showing elevated values in both elements (Table 5). Finally, the third group (Group C) has values below $68 \%$ wt. and above $1.5 \%$ wt., respectively, consisting of all the Rhodian samples with the addition of 8 Satricum samples and two samples from Spina. The sample close to group A can be considered either as a group A sample with marginal $\mathrm{SiO}_{2}$ content or as an outlier (SAT.11).

Evidence for the use of different sand sources can be derived from trace element characterization. Forty-five out of the total of 56 samples were analysed by means of LA-ICP-MS for the determination of their trace element compositions. The 45 samples analysed are part of group A and B samples (Fig. 3, Tables 1 and 6). Unfortunately, due to sampling criteria, none of group $\mathrm{C}$ samples were analysed by LA-ICPMS to identify their trace element composition. By plotting $\mathrm{Nd}$ against Sr, an interesting correlation can be seen (Fig. 4). There are two groups of samples with positive correlations between the two elements but with different slopes. Samples with a higher slope are part of the samples that form group A (see above) with only one addition (sample Sa.23), which has a basic glass composition similar to group $\mathrm{B}$ samples (high $\mathrm{Al}_{2} \mathrm{O}_{3}$, high $\mathrm{SiO}_{2}$ ). A similar positive correlation between these two elements was found in plant ash Late Bronze Age glass from Egypt and Greece (Henderson 2013). It has been suggested that the latter correlation was derived from the fact that plant ash was contributing to the excess of $\mathrm{Nd}$ and therefore the combination of plant ash and sand created this correlation (Henderson et al. 2010; Henderson 2013). This study is different because natron-based glasses have no contribution from plant ash so a different explanation needs to be sought. $\mathrm{Sr}$ is an element associated mainly with $\mathrm{Ca}$ and by implication primarily derived from shells in the sands used; however, a contribution from feldspars or/and heavy minerals in the silica source cannot be excluded (Henderson et al. 2005; Degryse et al. 2006, 2010). Nd is presumed to be related to accessory minerals such as zircon present in sand (Brems et al. 2014). Thus, differences in the $\mathrm{Nd} / \mathrm{Sr}$ ratio between the two groups could reflect use of sands with different proportions of "contaminant" minerals.

Strontium $(\mathrm{Sr})$, barium $(\mathrm{Ba})$ and zirconium $(\mathrm{Zr})$ are three elements, associated with various minerals in rocks or sediments and hence in derived sands. Their concentration varies and reflects the local geology of the sand precursors. 
Zirconium is expected to be primarily present as zircons in sands while $\mathrm{Sr}$ is connected with the presence of $\mathrm{Ca}$ which derives from shells (aragonite) or/and limestone. Barite $\left(\mathrm{BaSO}_{4}\right)$, which is found as concretions in sands and sandstones, is the likely main mineral in sands. These three elements can therefore be possible independent markers for differentiating sand sources used to make glasses.

In Fig. 5, a bi-plot of $\mathrm{Sr}$ versus $\mathrm{Zr}$ concentrations, samples divide into two groups. The majority of the samples form a group with low $\mathrm{Zr}$ values $(29-42 \mathrm{mg} / \mathrm{kg}$ ) and varying $\mathrm{Sr}$ compositions $(270-562 \mathrm{mg} / \mathrm{kg})$. Nine samples have elevated values of $\mathrm{Zr}$ (above $50 \mathrm{mg} / \mathrm{kg}$ ). Five of them (yellow diamonds) are part of group A samples and show a positive correlation. This clear distinction, between part of group A and the majority of group B samples, strengthens the idea that they were manufactured with different raw material sources. Four samples have values "between" the two main groups. This could reflect a third group or could be a result of recycling. This distinction is also obvious in our Ba against Zr plot (Fig. 6) where the majority of samples have elevated $\mathrm{Ba}$ and lower $\mathrm{Zr}$ values while there are some samples with elevated $\mathrm{Zr}$ values $(\sim 50<\mathrm{Zr}<130 \mathrm{mg} / \mathrm{kg})$ suggesting use of different sands (Shortland et al. 2007; Henderson 2013). The five samples (yellow diamonds) are again positively correlated while the four "recycled" have a distinct position in the plot. A comparison with relative levels of barium and zirconium in late Hellenistic and early Roman vessel glasses shows a clear distinction from many Satricum samples, especially for

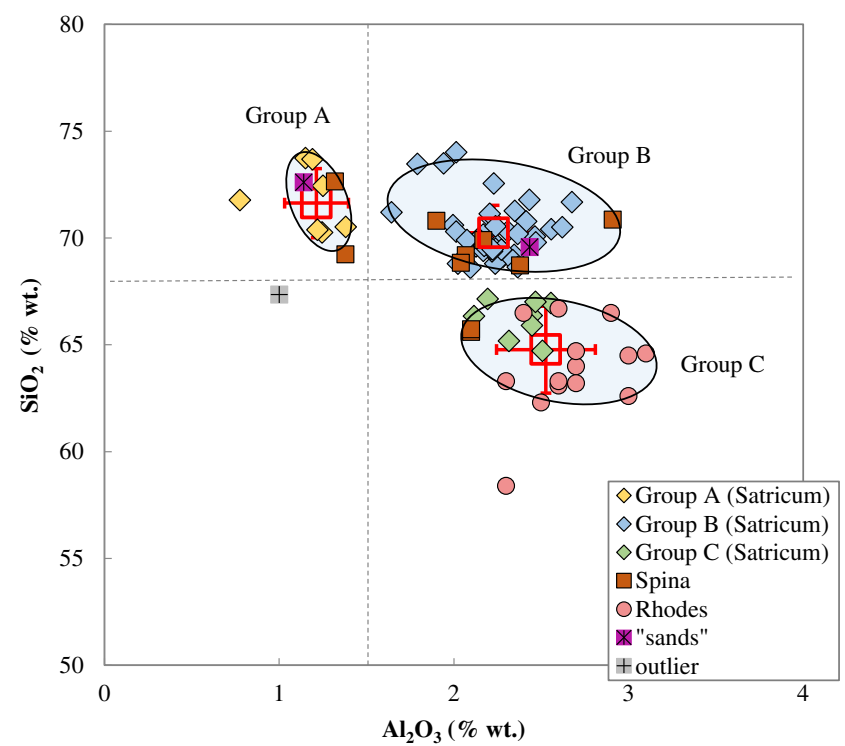

Fig. $3 \mathrm{Al}_{2} \mathrm{O}_{3}$ versus $\mathrm{SiO}_{2}$ concentrations in glasses from Satricum (this study), Spina and Rhodes samples. The samples are divided in 3 main groups (group $\mathrm{A}$ high $\mathrm{SiO}_{2} /$ low $\mathrm{Al}_{2} \mathrm{O}_{3}$, group $\mathrm{B}$ high $\mathrm{SiO}_{2}$ /high $\mathrm{Al}_{2} \mathrm{O}_{3}$ and group $\mathrm{C}$ low $\mathrm{SiO}_{2} /$ high $\mathrm{Al}_{2} \mathrm{O}_{3}$ ). In the same plot, mean values with 1 s.d. of each group are presented as well as the concentrations of two hypothetical glasses using sand suitable for glassmaking (Brems et al. 2012) 
Table 5 Major and Minor oxides detected by SEM-EDX (Sa.1-Sa.45) and EPMA (SAT.1-SAT.11) including min. max. mean and standard deviation (s.d.) values (in $\%$ w.t.)

\begin{tabular}{|c|c|c|c|c|c|c|c|c|c|c|c|c|c|}
\hline Sample & Inventory No. & Colour & Type & Group & $\mathrm{Na}_{2} \mathrm{O}$ & $\mathrm{MgO}$ & $\mathrm{Al}_{2} \mathrm{O}_{3}$ & $\mathrm{SiO}_{2}$ & $\mathrm{SO}_{3}$ & $\mathrm{Cl}$ & $\mathrm{K}_{2} \mathrm{O}$ & $\mathrm{CaO}$ & $\mathrm{Fe}_{2} \mathrm{O}_{3}$ \\
\hline Sa. 4 & CAT.7 & Dark blue & Unidentified & A & 19.11 & 0.63 & 1.25 & 72.45 & 0.18 & 1.08 & 0.29 & 4.66 & 0.35 \\
\hline Sa. 5 & CAT.9 & turquoise & Albastron & A & 18.23 & 0.57 & 1.25 & 70.26 & 0.51 & 1.05 & 0.33 & 7.13 & 0.67 \\
\hline Sa.16 & CAT.52 & Dark blue & Alabastron & A & 16.69 & 0.57 & 1.15 & 73.74 & 0.18 & 1.17 & 0.29 & 5.67 & 0.55 \\
\hline Sa.21 & CAT.64 & turquoise & Albastron & A & 17.92 & 0.48 & 1.22 & 70.38 & 0.46 & 1.06 & 0.27 & 7.48 & 0.72 \\
\hline Sa.35 & САТ.94 & Dark blue & Aryballos & A & 16.37 & 0.63 & 1.19 & 73.69 & 0.23 & 1.19 & 0.4 & 5.72 & 0.57 \\
\hline $\mathrm{Sa} .40$ & CAT.104 & Brown & Oinochoe & A & 17.91 & 0.62 & 0.78 & 71.77 & 0.46 & 1.35 & 0.27 & 6.51 & 0.34 \\
\hline SAT.5 & V565 & Blue & Unidentified & $\mathrm{A}$ & 16.51 & 0.59 & 1.38 & 70.52 & 0.17 & 1.22 & 0.34 & 7.15 & 0.9 \\
\hline Sa.1 & CAT.1 & Dark blue & Alabastron & $\mathrm{B}$ & 16.45 & 0.32 & 1.79 & 73.47 & 0.37 & 1.05 & 0.62 & 5.05 & 0.95 \\
\hline Sa. 2 & CAT.4 & Dark blue & Alabastron & $\mathrm{B}$ & 16.21 & 0.44 & 2 & 70.6 & 0.36 & 1.23 & 0.48 & 7.95 & 0.75 \\
\hline Sa.3 & CAT. 5 & Dark blue & Alabastron & $\mathrm{B}$ & 16.62 & 0.63 & 2.47 & 70.07 & 0.14 & 1.21 & 0.39 & 7.65 & 0.84 \\
\hline Sa. 6 & CAT.11 & Dark blue & Alabastron & B & 19.16 & 0.73 & 2.25 & 69.68 & 0.27 & 1.17 & 0.29 & 6.07 & 0.57 \\
\hline Sa.7 & CAT.13 & Dark blue & Alabastron & $\mathrm{B}$ & 17.47 & 0.53 & 2.13 & 69.6 & 0.2 & 1.33 & 0.5 & 7.43 & 0.81 \\
\hline Sa. 8 & CAT.15 & Dark blue & Alabastron & $\mathrm{B}$ & 17.71 & 0.58 & 2.24 & 69.49 & 0.24 & 1.42 & 0.48 & 7.19 & 0.77 \\
\hline Sa.9 & CAT.16 & Dark blue & Alabastron & $\mathrm{B}$ & 17.83 & 0.64 & 2.28 & 69.13 & 0.26 & 1.36 & 0.53 & 7.32 & 0.72 \\
\hline Sa.10 & CAT.36 & Dark blue & Alabastron & B & 17.1 & 0.36 & 2.35 & 71.28 & 0.39 & 0.96 & 0.56 & 6.27 & 0.73 \\
\hline Sa.11 & CAT.40 & Dark blue & Alabastron & $\mathrm{B}$ & 15.91 & 0.67 & 2.42 & 70.78 & 0.16 & 1.27 & 0.44 & 7.54 & 0.83 \\
\hline Sa.12 & CAT.42 & Dark blue & Alabastron & $\mathrm{B}$ & 16.94 & 0.53 & 2.31 & 70.31 & 0.22 & 1.17 & 0.44 & 7.18 & 0.9 \\
\hline Sa.13 & CAT.44 & Dark blue & Alabastron & B & 17.01 & 0.6 & 2.37 & 70.19 & 0.29 & 1.15 & 0.4 & 7.23 & 0.76 \\
\hline Sa.14 & CAT.45 & Dark blue & Alabastron & $\mathrm{B}$ & 17.22 & 0.93 & 2.21 & 70.91 & 0.29 & 1.01 & 0.62 & 6.01 & 0.8 \\
\hline Sa.15 & CAT.50 & Dark blue & Alabastron & $\mathrm{B}$ & 16.7 & 0.42 & 2.01 & 70.3 & 0.17 & 1.19 & 0.48 & 8.16 & 0.61 \\
\hline Sa.17 & CAT.54 & Dark blue & Alabastron & $\mathrm{B}$ & 16.6 & 0.38 & 1.94 & 73.49 & 0.4 & 0.91 & 0.59 & 4.79 & 0.82 \\
\hline Sa.18 & CAT.55 & Dark blue & Alabastron & $\mathrm{B}$ & 16.83 & 0.59 & 2.15 & 70.08 & 0.27 & 1.27 & 0.45 & 7.64 & 0.77 \\
\hline Sa.19 & CAT.57 & Dark blue & Alabastron & $\mathrm{B}$ & 19.43 & 0.69 & 2.35 & 69.22 & 0.15 & 1.17 & 0.36 & 6.12 & 0.53 \\
\hline Sa. 20 & CAT.58 & Dark blue & Alabastron & $\mathrm{B}$ & 19.52 & 0.66 & 2.34 & 68.96 & 0.22 & 1.25 & 0.42 & 6.08 & 0.57 \\
\hline Sa.22 & CAT.66 & Dark blue & Alabastron & $\mathrm{B}$ & 21.53 & 0.76 & 2.37 & 68.64 & 0.24 & 0.99 & 0.51 & 4.7 & 0.26 \\
\hline Sa.23 & CAT.68 & Dark blue & Alabastron & $\mathrm{B}$ & 16.53 & 0.3 & 2.01 & 74.01 & 0.47 & 0.77 & 0.49 & 4.84 & 0.58 \\
\hline Sa.24 & CAT.72 & Dark blue & Alabastron & $\mathrm{B}$ & 17.74 & 0.58 & 2.17 & 70.17 & 0.19 & 1.13 & 0.46 & 7.16 & 0.44 \\
\hline Sa. 25 & CAT.76 & Dark blue & Amphoriskos & $\mathrm{B}$ & 20.17 & 0.65 & 2.24 & 68.81 & 0.21 & 1.22 & 0.51 & 5.86 & 0.34 \\
\hline Sa.26 & CAT.78 & Dark blue & Amphoriskos & $\mathrm{B}$ & 17.63 & 0.66 & 2.27 & 69.46 & 0.25 & 1.28 & 0.46 & 7.24 & 0.76 \\
\hline Sa.27 & CAT.79 & Dark blue & Amphoriskos & $\mathrm{B}$ & 17.57 & 0.54 & 2.22 & 69.37 & 0.26 & 1.33 & 0.45 & 7.26 & 0.79 \\
\hline Sa.28 & CAT.81 & Brown & Amphoriskos & $\mathrm{B}$ & 18.58 & 0.5 & 2.1 & 68.61 & 0.3 & 1.47 & 0.55 & 7.55 & 0.34 \\
\hline Sa.29 & CAT.82 & Brown & Amphoriskos & $\mathrm{B}$ & 17.61 & 0.55 & 2.17 & 69.39 & 0.22 & 1.43 & 0.63 & 7.72 & 0.27 \\
\hline Sa.30 & CAT.83 & Brown & Amphoriskos & $\mathrm{B}$ & 18.22 & 0.56 & 2.02 & 68.81 & 0.33 & 1.54 & 0.54 & 7.74 & 0.24 \\
\hline Sa.31 & CAT.85 & Dark blue & Hydriskos & $\mathrm{B}$ & 17.72 & 0.61 & 2.21 & 69.49 & 0.11 & 1.42 & 0.42 & 7.24 & 0.84 \\
\hline Sa.32 & CAT.87 & Dark blue & Hydriskos & $\mathrm{B}$ & 18.57 & 0.68 & 1.64 & 71.2 & 0.23 & 1.2 & 0.36 & 5.57 & 0.55 \\
\hline Sa.33 & CAT.89 & Dark blue & Hydriskos & $\mathrm{B}$ & 17.74 & 0.54 & 2.14 & 69.97 & 0.21 & 1.41 & 0.54 & 6.69 & 0.76 \\
\hline Sa.34 & CAT.92 & Dark blue & Hydriskos & $\mathrm{B}$ & 17.03 & 0.5 & 2.21 & 71.14 & 0.3 & 1.15 & 0.47 & 6.54 & 0.66 \\
\hline Sa.36 & CAT.98 & Dark blue & Oinochoe & B & 16.99 & 0.76 & 2.56 & 70.41 & 0.49 & 0.83 & 0.54 & 6.88 & 0.53 \\
\hline Sa.37 & CAT.99 & Dark blue & Oinochoe & $\mathrm{B}$ & 17.99 & 0.72 & 2.17 & 69.63 & 0.49 & 1.05 & 0.58 & 6.64 & 0.73 \\
\hline Sa.38 & CAT.101 & Dark blue & Oinochoe & B & 18.16 & 0.6 & 2.08 & 69.91 & 0.57 & 0.97 & 0.59 & 6.46 & 0.64 \\
\hline Sa.39 & CAT.102 & Dark blue & Oinochoe & B & 16.85 & 0.72 & 2.62 & 70.51 & 0.45 & 0.73 & 0.53 & 6.95 & 0.65 \\
\hline Sa.41 & CAT.105 & Dark blue & Oinochoe & B & 16.1 & 0.33 & 2.43 & 71.8 & 0.45 & 1.04 & 0.5 & 6.91 & 0.45 \\
\hline Sa.42 & CAT.107 & Dark blue & Oinochoe & B & 16.44 & 0.44 & 2.23 & 72.55 & 0.36 & 1.03 & 0.51 & 6.17 & 0.35 \\
\hline $\mathrm{Sa} .43$ & V1091 & Dark blue & Bead & $\mathrm{B}$ & 17.23 & 0.56 & 2.68 & 71.69 & 0.19 & 1.02 & 0.33 & 5.23 & 1.09 \\
\hline $\mathrm{Sa} .44$ & Tomb 29a (V75) & Dark blue & Bead & $\mathrm{B}$ & 18.66 & 0.52 & 2.22 & 69.47 & 0.38 & 1.31 & 0.4 & 6.74 & 0.3 \\
\hline Sa.45 & Tomb 19 (V71) & Dark blue & Bead & $\mathrm{B}$ & 17.79 & 0.59 & 2.24 & 70.55 & 0.41 & 0.89 & 0.58 & 5.42 & 1.53 \\
\hline SAT.2 & V2088 & Dark blue & Oinochoe & $\mathrm{B}$ & 16.15 & 0.4 & 2.47 & 69.79 & 0.29 & 1.01 & 0.49 & 7.18 & 0.67 \\
\hline SAT.1 & V528 & Dark blue & Amphoriskos & $\mathrm{C}$ & 16.83 & 0.59 & 2.45 & 66.38 & 0.18 & 1.31 & 0.41 & 8.76 & 1.22 \\
\hline
\end{tabular}


Table 5 (continued)

\begin{tabular}{|c|c|c|c|c|c|c|c|c|c|c|c|c|c|}
\hline Sample & Inventory No. & Colour & Type & Group & $\mathrm{Na}_{2} \mathrm{O}$ & $\mathrm{MgO}$ & $\mathrm{Al}_{2} \mathrm{O}_{3}$ & $\mathrm{SiO}_{2}$ & $\mathrm{SO}_{3}$ & $\mathrm{Cl}$ & $\mathrm{K}_{2} \mathrm{O}$ & $\mathrm{CaO}$ & $\mathrm{Fe}_{2} \mathrm{O}_{3}$ \\
\hline SAT.3 & V22718 & Dark blue & Unidentified & $\mathrm{C}$ & 17.22 & 0.62 & 2.19 & 67.14 & 0.36 & 0.92 & 0.59 & 8.1 & 1.03 \\
\hline SAT.4 & V2160 & Dark blue & Alabastron & $\mathrm{C}$ & 16.87 & 0.62 & 2.45 & 65.91 & 0.18 & 1.18 & 0.39 & 8.88 & 1.17 \\
\hline SAT.6 & V730 & Dark blue & Unidentified & $\mathrm{C}$ & 17.55 & 0.41 & 2.56 & 66.95 & 0.3 & 1.12 & 0.37 & 8.47 & 0.83 \\
\hline SAT.7 & V2331 & Dark blue & Unidentified & $\mathrm{C}$ & 17.6 & 0.64 & 2.12 & 66.35 & 0.37 & 1.02 & 0.6 & 8.5 & 0.96 \\
\hline SAT.8 & V525 & Dark blue & Unidentified & $\mathrm{C}$ & 17.78 & 0.67 & 2.47 & 67.01 & 0.22 & 1.32 & 0.45 & 8.79 & 0.9 \\
\hline SAT.9 & V10443 & Dark blue & Unidentified & $\mathrm{C}$ & 17.84 & 0.41 & 2.51 & 64.72 & 0.37 & 0.96 & 0.48 & 6.89 & 0.93 \\
\hline SAT.10 & V2537 & Dark blue & Unidentified & $\mathrm{C}$ & 18.7 & 0.57 & 2.32 & 65.19 & 0.24 & 1.46 & 0.52 & 8.75 & 0.3 \\
\hline SAT.11 & V759 & Dark blue & Unidentified & Outlier & 15.76 & 0.52 & 1 & 67.36 & 0.28 & 1.03 & 0.35 & 8.62 & 1.01 \\
\hline Min & & & & & 15.76 & 0.3 & 0.78 & 64.72 & 0.11 & 0.73 & 0.27 & 4.66 & 0.24 \\
\hline Max & & & & & 21.53 & 0.93 & 2.68 & 74.01 & 0.57 & 1.54 & 0.63 & 8.88 & 1.53 \\
\hline Mean & & & & & 17.55 & 0.57 & 2.1 & 69.87 & 0.29 & 1.16 & 0.46 & 6.9 & 0.7 \\
\hline s.d. & & & & & 1.1 & 0.12 & 0.44 & 2.09 & 0.11 & 0.18 & 0.1 & 1.12 & 0.26 \\
\hline
\end{tabular}

Satricum samples containing below c. $200 \mathrm{mg} / \mathrm{kg}$ (ThirionMerle 2005; Henderson 2013, Fig. 8.3).

Among the 56 glass samples discussed in this paper, there are 53 fragments of glass vessels and 3 fragments of glass beads, the balance being sub-samples from the same objects of different colours. The 53 fragments are dark blue (47), brown (4) and turquoise (2); the 3 bead samples are dark blue. The deep blue colour, in all the vessel and bead samples, is associated with the presence of cobalt $(\mathrm{Co})$ and copper $(\mathrm{Cu})$ in varying concentrations, while the turquoise colour in 2 fragments is associated with high $\mathrm{Cu}$ levels. The 4 brown samples do not show anomalous values in any of the colourant elements so it can be assumed that their colouration is due to controlling the furnace atmosphere and therefore will be excluded from the following analysis.

As it can be seen in Fig. 7, the majority of samples have elevated values of both $\mathrm{Co}$ and $\mathrm{Cu}$ suggesting that they belong at the $\mathrm{CoCu}$ cobalt colouring glass category identified by various scholars for earlier glass samples (Shortland and Eremin 2006; Shortland et al. 2007; Smirniou and Rehren 2013). They are positively correlated with a $\mathrm{Co}: \mathrm{Cu}$ ratio close to 1 . There is also a cluster of samples (yellow ellipse) (Sa.14, Sa.36, Sa.37, Sa.38 and Sa.39) which have lower Co values. Also, samples Sa.5, Sa.21 show low Co (91 and $86 \mathrm{mg} / \mathrm{kg}$ ) and high $\mathrm{Cu}$ contents (5542 and $5307 \mathrm{mg} / \mathrm{kg}$ ) which is to be expected since they are turquoise. Five samples (Sa.4, Sa.16, $\mathrm{Sa} .41, \mathrm{Sa} .42$ and $\mathrm{Sa} .45$ ) can be considered as Co-blue glasses since their $\mathrm{Cu}$ values are below $850 \mathrm{mg} / \mathrm{kg}$, as suggested by Smirniou and Rehren (2013). The two glass beads (samples Sa.43-44) show high $\mathrm{Cu}$ content (above $3000 \mathrm{mg} / \mathrm{kg}$ ) and especially Sa.44 show high Co content (2683 mg/kg). The two beads, as it is seen on Fig. 7, do not fall in the same $\mathrm{CoCu}$ line like the majority of samples. Triantafyllidis (2001) has suggested that glass used to make beads was often recycled. Furthermore, Pliny the Elder in Natural History (XXXVI. 199) writes about recycling activities associated with the manufacture of glass beads. Therefore, the glass used for these two beads could be a result of recycling.

There are various minerals rich in cobalt, that have been proposed as colourant sources in ancient glasses, such as cobaltite (CoAsS), absolane (a mixture of $\mathrm{MnO}$ and $\mathrm{CoOOH}$ ), trianite $\left(2 \mathrm{Co}_{2} \mathrm{O} . \mathrm{CuO} \cdot 6 \mathrm{H}_{2} \mathrm{O}\right)$ and skutterudite $\left((\mathrm{Co}, \mathrm{Ni}, \mathrm{Fe}) \mathrm{As}_{3}\right)$ (Henderson 2013). Another common source of cobalt is cobaltiferous alums which are found mainly in Egypt but there are also alum ores in Iran, Turkey and Germany as well (Kazmarczyck 1986; Henderson 2013). Therefore, elements that can be associated with either minerals or alums include Al, Mn, Ni, Zn, As, Fe. In Fig. 8, the correlation between Mn and Co for vessels and beads of deep blue and turquoise colours is presented.

According to the plot, three major groups of samples can be distinguished, while there are five samples which are "outliers" (falling in the upper, lower and left part of the plot). The first group $(n=9)$ has low Mn values (between 100 and $200 \mathrm{mg} / \mathrm{kg}$ ) and variable Co values (700-1550 mg/kg). The majority of the samples $(n=19)$ fall in the centre of the plot having elevated values of both $\mathrm{Co}$ and $\mathrm{Mn}$ while the third group $(n=5)$ has low Co and high Mn contents. We can show that three different cobalt sources were used for the coloration of these samples.

Concerning the "outliers", all of them are group A samples except from the blue bead (Sa.44), which has high Mn content (2341 mg/kg) and elevated amount of Co (2683 mg/ $\mathrm{kg} \mathrm{Co})$. Combined with the fact that it has a notable level of $\mathrm{Cu}$ (4495 mg/kg), its composition can be considered to be a result of recycling. Among group A samples, there are two turquoise samples (Sa.21 and Sa.5) having low Co values (their coloration is due to high levels of Cu: 5307 and $5542 \mathrm{mg} / \mathrm{kg}$, respectively) and lastly there are two samples with the highest amount of $\mathrm{Mn}$ (Sa.4 and Sa.16), which is another indication that group A samples were manufactured not only with different primary raw materials (sand, see Fig. 3) but also with 


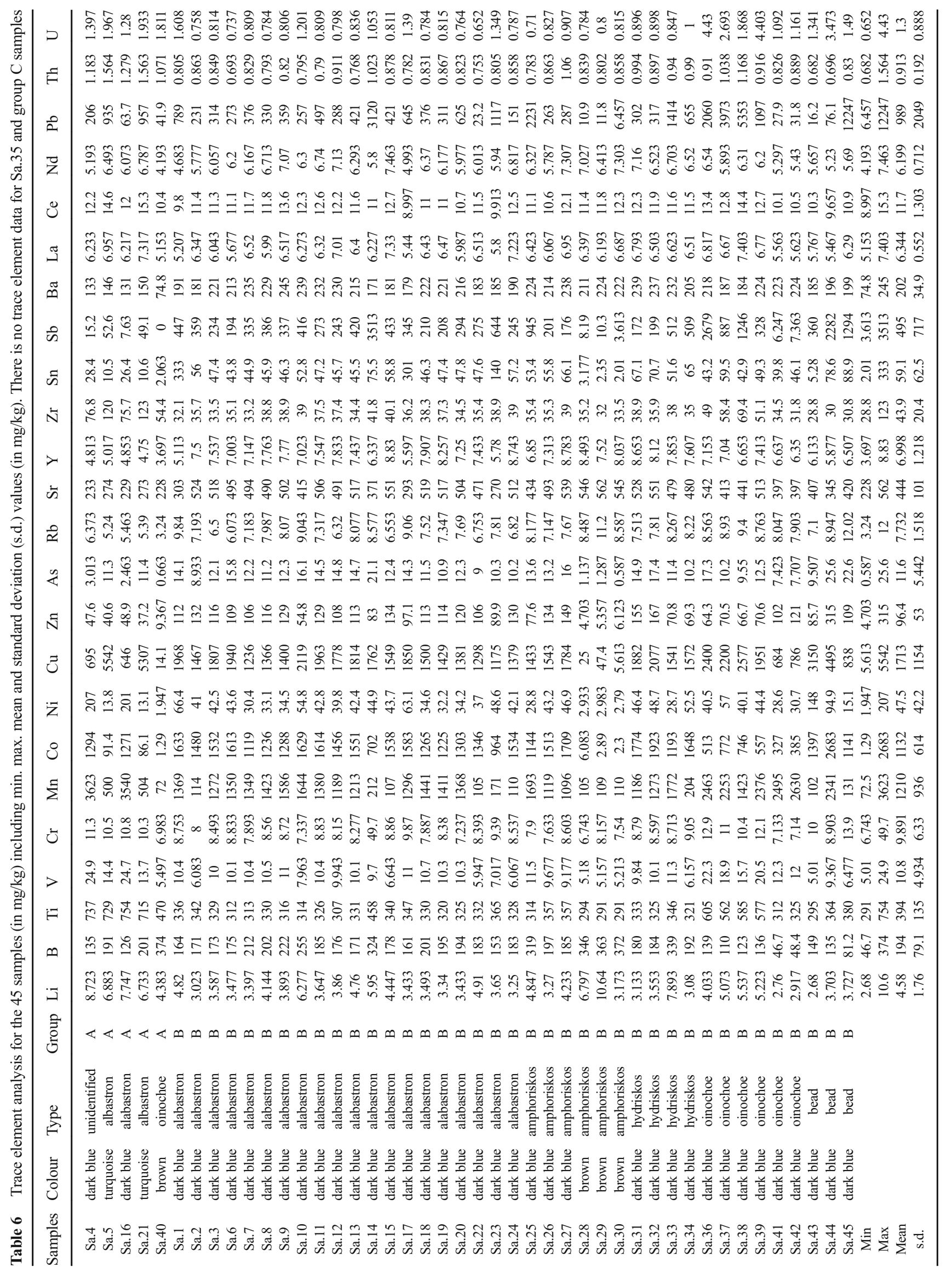




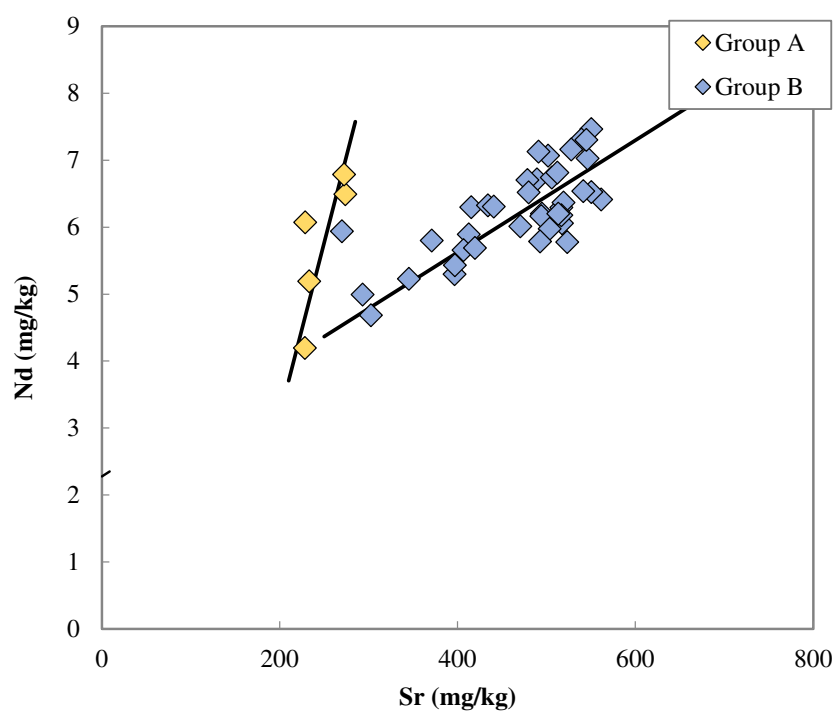

Fig. $4 \mathrm{Nd}$ versus $\mathrm{Sr}$ concentrations in 45 Satricum glass samples. The samples are divided in two groups with differing slopes which were calculated by maximum likelihood functions. The first group consists of six samples (part of group A samples see Fig. 3) and the second with the rest (group B samples see Fig. 3)

different secondary additives, indicating a totally different glassmaking tradition.

Excluding the outliers, if we plot the rest on a ternary diagram, the correlation between $\mathrm{Mn}, \mathrm{Co}$ and $\mathrm{Ni}$ becomes clear. In this diagram, we can note that the samples fall into three different groups with low, middle and high values of Mn. The high and low Mn samples seem to coincide and fall almost precisely into the two groups that Abe et al. (2012) have identified (the yellow ellipse in Fig. 9). The yellow ellipse in the middle of the graph is for samples coming from Egypt of the eighteenth Dynasty and therefore we can assume they have a totally different source of Co. According to Abe et al. (2012),

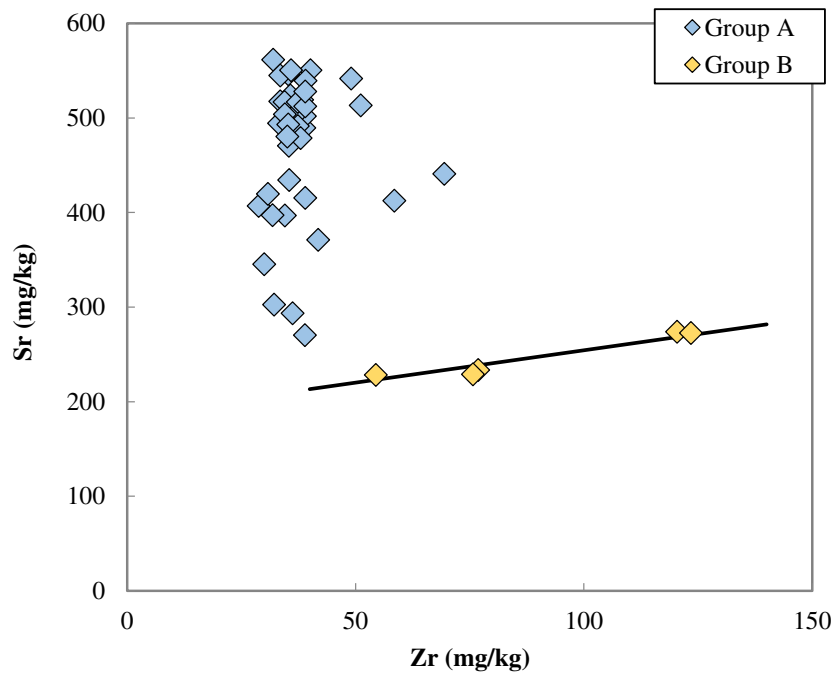

Fig. $5 \mathrm{Zr}$ versus $\mathrm{Sr}$ concentrations in Satricum glass samples. The samples are divided in two groups with high and low $\mathrm{Zr}$ levels and/or $\mathrm{Sr}$ levels. The samples with the positive correlation are part of group A samples (see Fig. 3)

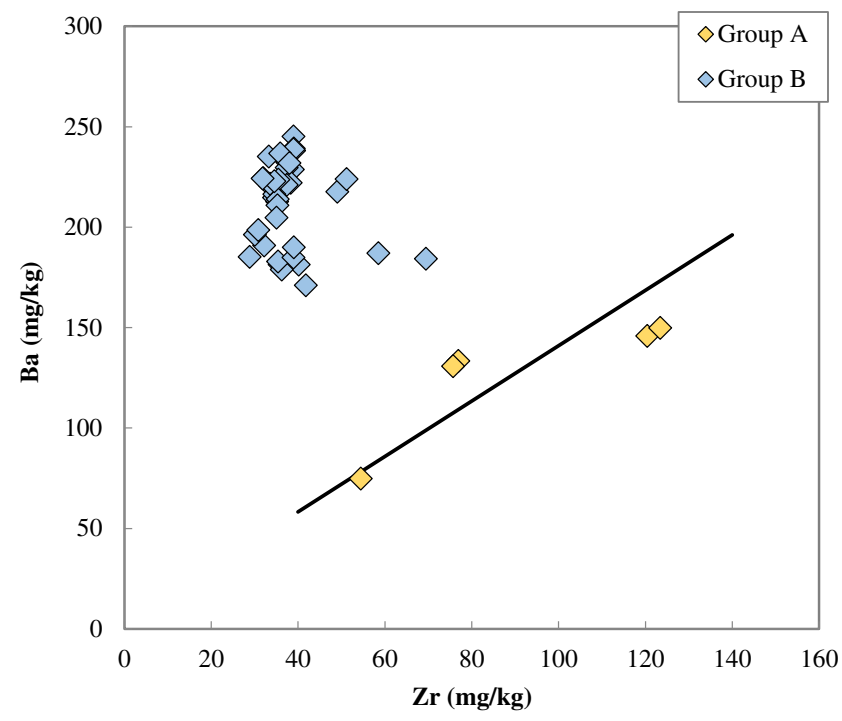

Fig. $6 \mathrm{Zr}$ versus $\mathrm{Ba}$ concentrations in Satricum glass samples. The samples are divided in two groups with high and low Ba levels. The samples with the positive correlation are part of group A samples (see Fig. 3). Colourants

Co in the lower group of samples is deriverd from Mn-rich cobaltiferrous ores such as asbolane which was mined at Iran. It is rather unclear what the Co source of the other two groups (with middle and low Mn content) is but cobaltiferrous alums from the Dakhla and Kharga oases in Egypt should be excluded since they show different chemical compositions in these trace elements (Shortland et al. 2006). Furthermore, differences in Mn values of cobalt blue glasses were also noted by Henderson (2000), where the chemical analyses of European Iron Age blue glass revealed a change in Co source in the second c. BC, from a Sb-rich source to a new Mn-rich source. In our assemblage, there is no correlation between $\mathrm{Sb}$ and $\mathrm{Co}$,

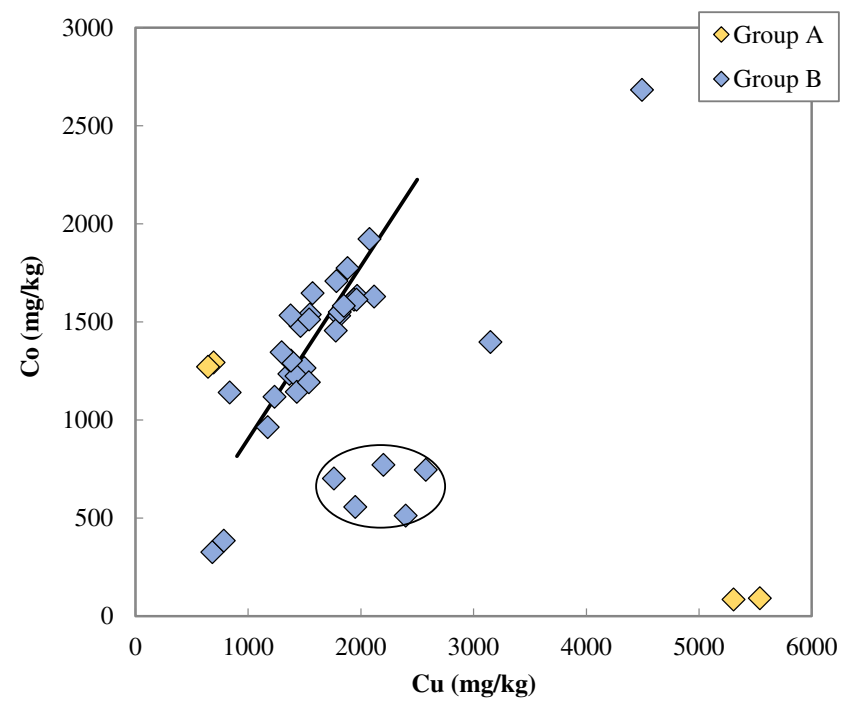

Fig. $7 \mathrm{Cu}$ versus Co concentrations in Satricum glass samples. The majority of Satricum samples are positively correlated (blue diamonds), and they are coloured with the $\mathrm{Cu}$ and $\mathrm{Co}$ 


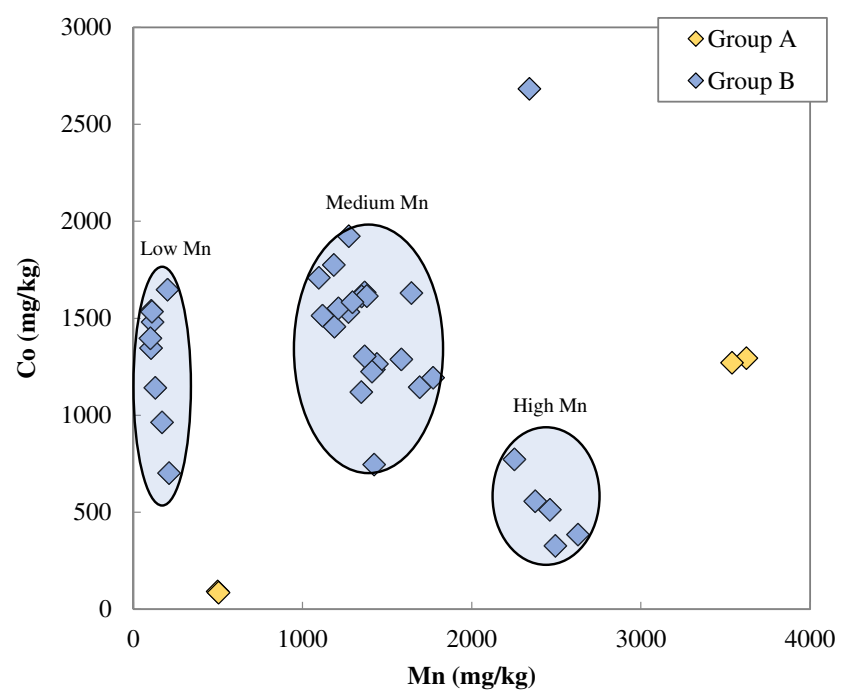

Fig. 8 Mn versus Co concentrations in Satricum glass samples. There are three distinguishable groups from left to right with low $\mathrm{Mn}$ high Co, high Mn high Co and high Mn low Co content

and we can assume that $\mathrm{Sb}$ was introduced in the glass as an opacifying agent rather than as an impurity of the Co source.

\section{Discussion}

From our previous discussion of the basic compositions of Italian glasses and the colourants used, we can extract useful conclusions concerning their technology. From the analysis of major minor and trace elements, we can suggest a model of production that involves the manufacture of the base glass and the coloration of it as two different processes. Therefore, we

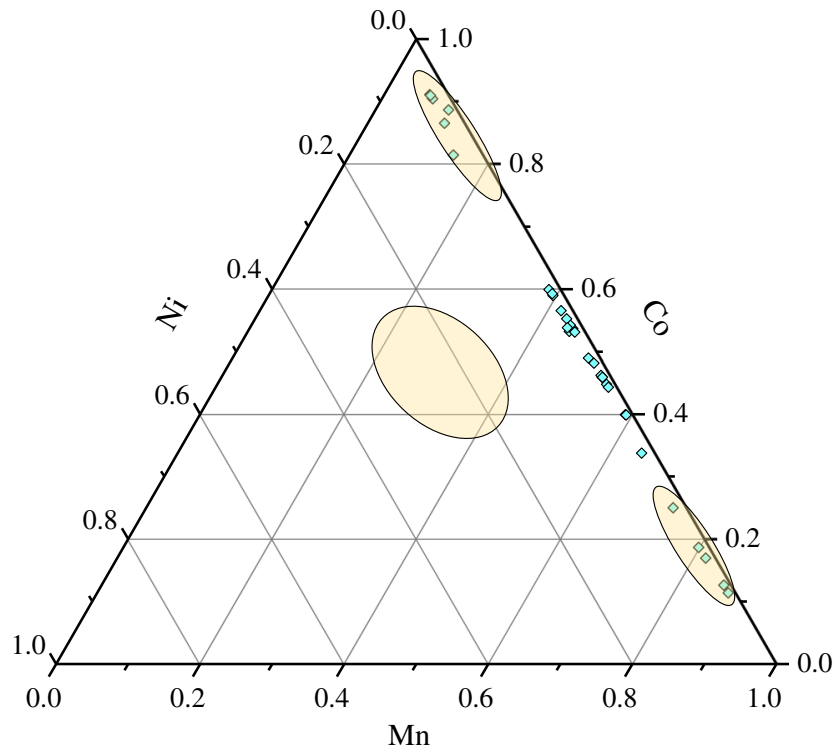

Fig. 9 Ternary plot of Mn, Co and Ni in cobalt blue glasses. Satricum samples do not correlate with Egyptian coeval samples (yellow ellipse in the middle) (Abe et al. 2012). A third group of samples exists between the two elongated ellipses suggesting a possible third source of Co can suggest a two-stage procedure. In the first stage, the base glass was fused using sand and natron as an alkali source. In the second stage, which probably formed part of a secondary glassmaking process when the base glass was reheated, colourants were mixed with the base glass; the glass vessels were then created (Fig. 10). This can be suggested because all group B samples can be divided into 3 broad groups depending on their Mn content which is associated with the colouring agents, mainly Co. Even if manganese oxide is present in the base glass, the use of variable $\mathrm{Mn}$ impurities in different cobalt-bearing minerals would produce the compositional variations that we have observed.

In the first stage, three different base glass compositions can be distinguished according to their relative $\mathrm{Al}_{2} \mathrm{O}_{3}$ and $\mathrm{SiO}_{2}$ levels, as discussed in relation to Fig. 3. Therefore, we probably have evidence for the use of three different sand sources and a common natron source. Group $\mathrm{C}$ samples have similar values to those found in Rhodian glass and, therefore, the silica can be considered as deriving from the same origin as Rhodian samples. The island of Rhodes Island played an important role as a glassmaking centre of core-formed vessels (especially Mediterranean core-formed group I vessels) during the late sixth and fifth c. BC (Harden 1981; Grose 1989; Triantafyllidis 2003). The continuity of the core-formed industry in the succeeding centuries can be attested by various finds (products of incomplete firing) (Weinberg 1966; Triantafyllidis 2000a, b). Therefore, group C samples can be either attributed to a "Rhodian" manufacturing centre or one that produced the glass that was used to make Rhodian vessels. It was certainly a different manufacturing centre from our group A and B samples.

It is quite interesting that 3 hypothetical glasses, manufactured from sands suitable for glassmaking of Roman period, have common characteristics with group A and B samples - and these are plotted with the data in Fig. 3. The concentration of these hypothetical glasses was calculated by Brems et al. (2012). Taking into consideration that the source of sand probably did not change significantly in the era after the Mediterranean Group II industry, we could hypothesise that group B vessels were manufactured most likely with sands coming from Italy, especially sands from Salentina peninsula (South Italy) and/or Tuscany (Brems et al. 2012).

This suggestion fits well with the archaeological record according to which the provenance of most of the Mediterranean group II vessels is southern Italy (Harden 1981; Grose 1989; Stern and Schlick-Nolte 1994). However, alternative regions in mainland Greece, such as Macedonia, have been suggested (McClellan 1984).

Supporting evidence for this conclusion is that Mediterranean group II vessels are found far more frequently in Italy and Magna Graecia than in the Aegean, Egypt, the Levant and Western Asia (Grose 1989). Our group B samples form a consistent group of 40 samples with the majority of 
Fig. 10 A proposed model for the manufacturing processes of Satricum samples

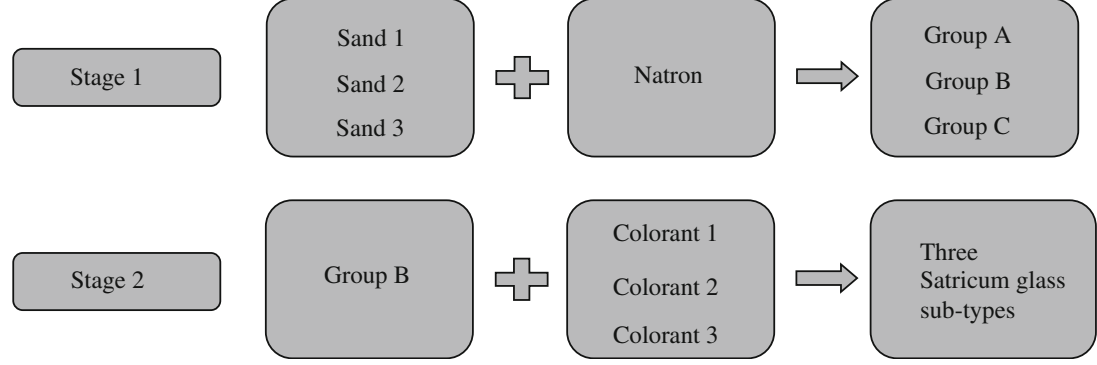

One of the groups (group A) can be considered as being imported from a currently unattributed source; a second group (group B) has characteristics consistent with an Italian origin; a third set of samples (group C) can probably be attributed to a Rhodian origin. There is a strong indication that group B samples were manufactured somewhere in Italy taking into account both archaeological and scientific/technological factors. Even though there is not any archaeological evidence for primary glass production during the Hellenistic period in Italy, certain scholars believe that production of core-formed vessels type II (after Grose 1989) took place somewhere in southern Italy. This interpretation combined with the fact that glass samples have similar compositions with Italian sands suitable for glassmaking provide a solid indication for a production in this region or/and in Southern Italy.

A two-stage manufacturing process can be suggested for Satricum $\mathrm{G}$ group B samples. In the first stage, the basic glass composition would have been produced and in the second stage colourants were added to the glass melt. The majority of samples, as characterised by trace elements, have a common cobalt colourant source which can probably be located in Iran especially in central Iran, rather than Egypt, while the outliers exhibit totally different trace element characteristics enhancing the belief that they were manufactured using a totally different set of raw materials or/and a different glass technology.

Acknowledgments AO would like to acknowledge that the study has been carried out under the support of the research programme Glasstech2013-Continuity and change in the emergence of the Hellenistic Glass industry in Greece, project number: 623645, FP7PEOPLE-2013-IEF, Marie Curie Actions, Intra-European Fellowships (IEF).

SC publishes with the permission of the Director, British Geological Survey.

The authors would like to acknowledge the Soprintendenza Archeologica del Lazio e dell'Etruria meridionale and the SatricumProject (University of Amsterdam) for giving permission to study the samples.

Open Access This article is distributed under the terms of the Creative Commons Attribution 4.0 International License (http:// creativecommons.org/licenses/by/4.0/), which permits unrestricted use, distribution, and reproduction in any medium, provided you give appropriate credit to the original author(s) and the source, provide a link to the Creative Commons license, and indicate if changes were made. 


\section{References}

Abe Y, Harimoto R, Kikugawaa T, Yazawa K, Nishisaka A, Kawai N, Yoshimura S, Nakai I (2012) Transition in the use of cobalt-blue colorant in the new kingdom of Egypt. J Archaeol Sci 39:1793-1808

Arletti R, Rivi L, Ferrari D, Vezzalini G (2011) The Mediterranean group II: analyses of vessels from Etruscan contexts in Northern Italy. J Archaeol Sci 38:2094-2100

Beltsios KG, Oikonomou A, Zacharias N, Triantafyllidis P (2012) Characterization and provenance of archaeological glass artifacts from mainland and Aegean Greece. In: Liritzis I, Stevenson C (eds) The dating and provenance of volcanic and ancient manufactured glasses-a global overview. University of New Mexico Press, Albuquerque, pp. 166-184

Brems D, Degryse P, Hasendoncks F, Gimeno D, Silvestri A, Vassilieva E, Luypaers S, Honings J (2012) Western Mediterranean sand deposits as a raw material for roman glass production. $\mathrm{J}$ Archaeol Sci 39:2897-2907

Brems D, Ganio M, Degryse P (2014) The Sr-Nd isotopic fingerprint of sand raw materials, glass making in the Greco-Roman World. Leuven University Press, Leuven

Brill RH (1988) Scientific investigations of the Jalame glass and related finds. In: Weinberg GD (ed) Excavations at Jalame, Site of a Glass Factory in Late Roman Palestine. University of Missouri Press, Columbia, pp. 257-294

Brill RH (1999) Chemical analyses of early glasses, volume 2, tables of analyses. The Corning Museum of Glass, Corning

Connolly P, Rehren T, Doulgeri-Intzesiloglou A, Arachoviti P (2012) The Hellenistic glass of Pherai, Thessaly. In: Ignatiadou D, Antonaras A (eds) Annales du $18^{\mathrm{e}}$ Congrès del' Association Internationale pour l'Histoire du Verre, pp. 91-97

Degryse P (ed) (2014) Glass making in the Greco-roman world. Leuven University Press, Leuven

Degryse P, Schneider J, Haack U, Lauwers V, Poblome J, Waelkens M, Muchez P (2006) Evidence for glass 'recycling' using $\mathrm{Pb}$ and $\mathrm{Sr}$ isotopic ratios and Sr-mixing lines: the case of early byzantine Sagalassos. J Archaeol Sci 33:494-501

Degryse, P., Freestone, I.C., Schneider, J., Jennings, S., 2010. Technology and provenance of Levantine plant ash glass using $\mathrm{Sr}-\mathrm{Nd}$ isotope analysis, Glass in Byzantium-Production, Usage, Analyses, International Workshop organised by the Byzantine Archaeology Mainz, 17th-18th of January 2008, Mainz, Mainz.

Gnade M (2002) Satricum in the post-archaic period: a case study of the Interpretation of Archaeological remains as Indicators of EthnoCultural Identity, Leuven

Gnade M (ed) (2007) Satricum. Trenta anni di scavi olandesi, (exhibition catalogue Le Ferriere 2007), Leuven

Grose DF (1989) Early Ancient Glass: Core-formed, Rod-formed, and Cast Vessels and Objects from the Late Bronze Age to the Early Roman Empire, $1600 \mathrm{BC}$ to $50 \mathrm{AD}$. The Toledo Museum of Art. Hudson Hills Press in Association with the Toledo Museum of Art, New York

Harden, D., 1981. Catalogue of Greek and Roman Glass in the British Museum, vol. I, London.

Henderson J (2000) The science and archaeology of materials: an investigation of inorganic materials. Routledge, London and New York

Henderson J (2013) Ancient Glass, an Interdisciplinary Exploration. Cambridge University Press, New York and Cambridge

Henderson J, Evans JA, Sloane HJ, Leng MJ, Doherty C (2005) The use of oxygen, strontium and lead isotopes to provenance ancient glasses in the Middle East. J Archaeol Sci 32:665-673

Henderson J, Evans J, Nikita K (2010) Isotopic evidence for the primary production, provenance and trade of late bronze age glass in the Mediterranean. Mediterr Archaeol Archaeometry 10(1):1-24
Jackson CM, Smedley JW, Booth CM (2005) Glass by design? Raw materials, recipes and compositional data. Archaeometry 47(4):781-795

Jochum KP, Weis U, Stoll B, Kuzmin D, Yang Q, Raczek I, Jacob DE, Stracke A, Birbaum K, Frick DA, Günther D, Enzweiler J (2011) Determination of reference values for NIST SRM 610-617 glasses following ISO guidelines. Geostandards Geoanalytical Res 35(4): 397-429

Kazmarczyck A (1986) The source of cobalt in ancient Egyptian pigments. In: Olin JS, Blackman J (eds) Proceedings of the 24th International Symposium on Archaeometry. Smithsonian Institution Press, Washington, DC, pp. 369-376

Lahlil S, Biron I, Galoisy L, Morin G (2008) Rediscovering ancient glass technologies through the examination of opacifier crystals. Appl Phys A 92:109-116

McClellan MC (1984) Core-formed glass from dated contexts. Ph.D Dissertation, University of Pennsylvania, Philadelphia

Nicholson PT, Henderson J (2000) Glass. In: Nicholson PT, Shaw I (eds) Ancient Egyptian materials and technology. Cambridge University Press, Cambridge, pp. 195-224

Oikonomou A, Triantafyllidis P, Beltsios K, Zacharias N, Karakassides M (2008) Raman structural study of ancient glass artefacts from the island of Rhodes. J Non-Cryst Solids 354(2-9):768-772

Oikonomou A, Beltsios K, Zacharias N (2012) Analytical and technological study of an ancient glass collection from Thebes, Greece: an overall assessment. In: Ignatiadou D, Antonaras A (eds) Annales du $18^{\mathrm{e}}$ Congrès del' Association Internationale pour l'Histoire du Verre, pp 81-86

Oikonomou A, Beltsios K, Zacharias N, Triantafyllidis P (2014) Technological and provenance study of archaic glassy materials from Rhodes Island using XRF and SEM/EDX analysis. Proceedings of the 39th International Symposium on Archaeometry, 28 May - 1 June 2012, Leuven, Belgium, pp 245-250

Palamara E, Zacharias N, Kamitsos EI, Oikonomou A, Palles D, Möncke D (2015) Spectroscopic study of a historical glass collection from Thebes, Greece, by Raman and IR, in: Photos Jones E (ed) in collaboration with Bassiakos Y, Filippaki E, Hein A, Karatasios I, Kilikoglou V, Kouloumpi E. Proceedings of the 6th Symposium of HAS, British Archaeological Reports, pp 59-64

Rehren Th, Spenser L, Triantafyllidis P (2005) The primary production of glass at Hellenistic Rhodes. Annales du 16e Congrès de l' Association Internationale pour l' Histoire du Verre, London 2003, Nottingham: International Association for the History of Glass, pp 39-43

Rehren T, Connolly P, Schibille N, Schwarzer H (2015) Changes in glass consumption in Pergamon (Turkey) from Hellenistic to late byzantine and Islamic times. J Archaeol Sci 55:266-279

Sayre EV, Smith RW (1961) Compositional categories of ancient glass. Science 133:1824-1826

Shortland AJ (2004) Evaporites of the WadiNatrum: seasonal and annual variation and its implication for ancient exploitation. Archaeometry 46(4):497-517

Shortland AJ, Eremin K (2006) The analysis of second millennium glass from Egypt and Mesopotamia, part 1: new WDS analyses. Archaeometry 48(4):581-603

Shortland AJ, Tite MS, Ewart I (2006) Ancient exploitation and use of cobalt alums from the Western oases of Egypt. Archaeometry 48: $153-168$

Shortland AJ, Rogers N, Eremin K (2007) Trace element discriminants between Egyptian and Mesopotamian late bronze age glasses. J Archaeol Sci 34:781-789

Smirniou M, Rehren T (2013) Shades of blue-cobalt-copper coloured blue glass from new kingdom Egypt and the Mycenaean world: a matter of production or colourant source? J Archaeol Sci 40:4731-4773

Sokaras D, Karydas A, Oikonomou A, Zacharias N, Beltsios K, Kantarelou V (2009) Combined elemental analysis of ancient glass beads by means of ion-beam, portable XRF and EPMA techniques. Anal Bioanal Chem 395:2199-2209 
Stern EM, Schlick-Nolte B (1994) Early Glass of the Ancient World, 1600 B.C.-A.D. 50. Enesto Wolf Collection, Ostifildern

Thirion-Merle V (2005) Les verres de Beyrouth et les verres du haut empire dans le monde occidental: étude archéométrique'. J Glass Stud 47:37-53

Triantafyllidis P (2000a) Rhodian Glassware I. The luxury hot-formed transparent vessels of the classical and early Hellenistic periods. Ministry of the Aegean Sea, (in Greek), Athens

Triantafyllidis P (2000b) New evidence of the glass manufacture in classical and Hellenistic Rhodes. Annales du 14e Congrès de l'Association Internationale pour l' Histoire du Verre: Venezia Milano 1998, Lochem, pp 30-34

Triantafyllidis P (2001) Recycling of glass in ancient Rhodes. Archaeol Arts 79:76-80 (in Greek)

Triantafyllidis P (2003) Classical and Hellenistic glass workshops from Rhodes, Échanges et commerce du verre dans le monde antique, Actes du colloque de l' association Française pour l' Archéologie du verre, Aix-en-Provence et Marseille, 7-9 Juin, 2001, Éditions Monique Mergoil, Montagnac
Triantafyllidis P, Karatasios I, Andreopoulou-Magkou E (2012) Study of core-formed glass vessels from Rhodes. In: Zacharias $\mathrm{N}$, Georgakopoulou M, Polikreti K, Fakorellis G, Vakoulis Th eds). Proceedings of the 5th Symposium of HSA, University of Peloponnese Publications, pp. 529-544, (in Greek)

Wagner B, Nowak A, Bulska E, Hametner K, Günther D (2012) Critical assessment of the elemental composition of corning archaeological reference glasses by LA-ICP-MS. Anal Bioanal Chem 402(4): $1667-1677$

Weinberg G (1966) Evidence for glass making in ancient Rhodes. Mélanges offerts à K. Michalowski, Warsaw, pp 709-712

Zacharias N, Beltsios K, Oikonomou A, Karydas AG, Aravantinos V, Bassiakos Y (2008a) Thermally and optically stimulated luminescence properties of an archaeological glass collection from Thebes, Greece. J Non-Cryst Solids 354(2-9):761-767

Zacharias N, Beltsios K, Oikonomou A, Karydas AG, Bassiakos Y, Michael CT, Zarkadas C (2008b) Solid-state luminescence for the optical examination of archaeological glass beads. Opt Mater 30(7): $1127-1133$ 